\title{
The Multiple Violations of Conversational Maxims in Lying Done by the Characters in Some Episodes of Desperate Housewives
}

\author{
Anneke H. Tupan, Helen Natalia \\ English Department, Faculty of Letters, Petra Christian University, \\ Siwalankerto 121-131, Surabaya, East Java, Indonesia \\ e-mail: atupan@peter.petra.ac.id
}

\begin{abstract}
The study on the characters' multiple violations in Desperate Housewives film shows that in violating the maxims, each person has his own reason specifically in lying. Using Grice's Cooperative Principle and Christoffersen's criteria of lying, the findings revealed that violating all maxims was meant to eliminate the interlocutor's chance to respond, violating three maxims was to cover the truth and violating two maxims was to create another lie in the future.
\end{abstract}

Key words: multiple violations

In a conversation, a speaker and a hearer are supposed to respond to each other in their turn and exchange with the needed information that benefits both of them (Crowley \& Mitchell, 1994, p.140). By giving the required information, they can understand each other's utterances and their conversations become smooth. The speaker and the hearer are said to have fulfilled the Cooperative Principle when they manage to achieve a successful conversation. According to Grice (1975, p. 45), Cooperative Principle which consists of four maxims (maxim of quality, quantity, relevance and manner) are the suggested principles for the speaker and the hearer to show their cooperation by giving appropriate contribution in their conversation. By applying Cooperative Principle, the speaker allows the hearer to draw assumptions about the speaker's intentions and the implied meaning.

However, people sometimes cannot fulfill those maxims and they seem to disobey them. Grice (as cited in Cutting, 2002, p. 40) says that when the speaker does not fulfill or obey the maxims, the speaker is said to "violate" them. Violation is the condition where the speakers do not purposefully fulfill certain maxim. When the speakers do maxim violation, 
the conversation between the speakers and the hearers can be unsuccessful since they will misunderstand each other. Speakers who violate a maxim cause the hearer not to know the truth and only understand the surface meaning of the speaker's words. In doing so the speaker can violate more than one maxim at the same time and the writers later name it as the multiple violations.

For some purposes, people tend to tell a lie. They believe that a lie is the natural tool to survive and to avoid them from anything that may put them in an inappropriate condition (Christoffersen, 2005). However, the major purpose for people to tell a lie is that they want to save their face. Sometimes, when people do something bad, they have no choice but lie to cover up their secret and to save their face. There are many reasons for people to lie such as to hide the truth, to please the hearer, or maybe the speaker envies other people, and many others.

Brown and Yule (1983, p. 32) give a further description on the conversational maxims proposed by Grice (1975, p. 45). Maxim of quantity means that speakers should be as informative as is required, that they should give neither too little information nor too much. Some speakers like to point to the fact that they know how much information the hearer requires or can be bothered with. People who give too little information risk their hearer not to be able to identify what they are talking about because they are not explicit enough. On the other hand, those who give more information than the hearer needs risk boring them. The effect of this maxim is to present that the statement is the strongest, or most informative, that can be made in the situation.

The second maxim is the maxim of quality, which says that speakers are, expected to be sincere, to be saying something that they believe correspond to reality. They are assumed not to say anything that they believe to be false or anything for which they lack evidence. Some speakers like to draw their hearer's attention to the fact that they are only saying what they believe to be true, and that they lack adequate evidence.

The third maxim is the maxim of relevance, which says that speakers are assumed to be saying something that is relevant to what has been said before. While the fourth maxim is the maxim of manner, which says that speakers should be brief and orderly, and avoids obscurity and ambiguity.

However, no one actually speaks like that the whole time; each conversation may contain the purpose of the speakers. These purposes can be good or bad both for the speakers and the hearers. Although Grice (1975, p.45) makes guidelines for the speakers to be cooperative in having 
conversation, sometimes people may disobey some maxims in order to achieve their purpose. A speaker can be said to violate a maxim when they know that the hearer will not know the truth and will only understand the surface meaning of the words.

If a speaker violates the maxim of quantity, they do not give the hearer enough information to know what is being talked about, because they do not want the hearer to know the full picture. The speaker is not implying anything, they are "being economical with the truth", for example:

[The setting: A (a guest) wants to be nicer and friendlier, he smiles to $B$ ( $a$ receptionist) and says hello politely. A dog comes and stands beside him. Then A asks B:]

A : Does your dog bite?

$B:$ No

A : (bends down to stroke it and gets bitten) Ow! You said your dog does not bite!

$B$ : That is not my dog.

(Cutting, 2002, p. 40)

$B$ actually knows that $A$ is talking about the dog which is beside $B$ and not B's dog at home, yet B intentionally does not give A enough information, for reasons best known to A herself.

If a speaker violates maxim of quality, they are not being sincere and giving the hearer the wrong information, example:

A: How much did that new dress cost, darling?

$B$ : (see the tag-50 pounds, but says...) Thirty-five pounds

(Cutting, 2002, p. 40)

When the husband (A) asks "how much did that new dress cost, darling?" , (B) violates the maxim of quality by not being sincere, and giving him the wrong information "thirty-five pounds" instead of "fiftypounds".

However, in answering the question: "how much did that new dress cost, darling?", the wife could have answered by violating the maxim of relation, in order to distract him and change the topic. For example:

(The Setting: A (husband) is the one who earns money, and the economy condition is bad. He sees $B$ (wife) wears an unusual dress. Then asks:)

B: I know, let's go out tonight. Now, where would you like to go?

(Cutting, 2002, p. 40) 
In another situation, in answering the question: "how much did that new dress cost, darling?", the wife could also have violated the maxim of manner by saying:

(The Setting: A (husband) is not the only one who earns money, but the economy condition is bad. He sees B (wife) wears an unusual dress. Then asks:)

A : How much did that new dress cost, darling?

$B$ : A tiny fraction of my salary, though probably a bigger fraction of the salary of the woman that sold it to me.

(Cutting, 2002, p. 40)

Christoffersen (2005) says that in real life situation, people tend to tell lies for different reasons. The following reasons will be used in the analysis to interpret the data. They are:

1. Hide the truth

Example : (John covers his real age to his sister's friend whom he met at the party by telling her that they have the same age)

A : I am twenty years old, and how old are you?

B : Exactly the same.

2. Save face

Example: (Ann covers herself for being shoplifter in front of people)

A : What is in your bag? I think our bracelet is in it

B : I - I do not know what you are talking about. I do not have any bracelet.

That alarm must be wrong.

3. Feel jealous about something

Example: (Cindy lies to Jane that she doesn't know Jim, the new student. Cindy actually likes him.)

A : I know you talked to Jim, this morning. He is awesome. What do you think about him?

B : I don't know what you are talking about.

4. Satisfying the hearer

Example: (A conversation between a mother and her son)

A : Mom, how was I born?

B : Uhm... because God loves you so He sends you to me as a gift

5. Cheer the hearer

Example: (a wife asks her husband whether she looks OK with the purple blouse or not. Her husband who hates purple, cheers his wife by giving an answer that is expected by his wife) 
A : Honey, does this color nice?

B : Of course sweetheart, you look gorgeous.

6. Avoiding to hurt the hearer

Example: (a mother of three years old boy wants to protect his son by telling that his father has gone overseas rather than saying that he died)

A : Mummy, where is Daddy?

B : Daddy has gone overseas because he wants to buy some toys for you

7. Building one's belief

Example: (Joan asks her boyfriend whether he still remembers his ex girlfriend or not. Her boyfriend lies to her and makes her believe 100\%)

A : I wonder if you are still in love with your ex.

B : Of course not darling, you know you are the one in my heart. (Fact: he is still in love with his ex)

A : But how come you still keep her photo in your wallet?

B : That is not her; she is my cousin who looks like her. (Fact: that's his ex's photo)

8. Convincing the hearer

Example: (a part time clerk asks his friend to take his shift, but his friend refuses by creating a good reason)

A : Can you take my shift tonight?

B : I wish I could, but I have to take my daughter to the dentist.

In the real life situation, many people tend to tell lie and break the rules of Grice's Cooperative Principle (1975, p. 45) when they communicate. They even do multiple violations for lying purposes. This is pictured in an American movie series on television entitled Desperate Housewives. It is an interesting film since it combines elements of drama, comedy, mystery, thriller, farce, soap opera and satire (Desperate Housewives, n.d.) It is about the life of four American housewives who live in the same neighborhood. They are desperate in their life because of love, betrayals, scandals, and conflicts among themselves. Therefore, they often lie to each other. This means that they often violate the maxims in their lies and do multiple violations to smooth them in which each lie seems to have purposes behind. 


\section{METHODOLOGY}

This was a descriptive qualitative study in which the data were the utterances taken from thirty-five episodes (seasons two and three) of a film entitled Desperate Housewives. They were chosen because they had a great deal of problems, conflicts and lies that happened among the characters.

The data were collected by identifying the conversations that contained lies based on Conversational Maxims suggested by Grice (1975), classifying the violations of maxims per episode and per character into tables, and finding the reason of the speaker who violated more than one maxim. Markers of violation were set up based on Cooperative Principle suggested by Grice (1975, p. 45).

The criteria of violation of maxims used as distinguished guidelines

\begin{tabular}{ll}
\hline Maxim & Violating the maxims \\
\hline Quantity & - If the speaker does circumlocution or not to the point \\
- If the speaker is uninformative \\
- If the speaker talks too short \\
- If the speaker talks too much \\
- If the speaker repeats certain words \\
\hline - If the speaker lies or says something that is believed to be \\
- false \\
- If the speaker does irony or makes ironic and sarcastic \\
- statement \\
- If the speaker denies something \\
- If the speaker distorts information \\
- If the speaker makes the conversation unmatched with the \\
- topic \\
- If the speaker changes conversation topic abruptly \\
- If the speaker avoids talking about something \\
- If the speaker does the wrong causality
\end{tabular}

(Grice, 1975, p. 45) 


\section{FINDINGS AND DISCUSSION}

The findings showed that there were three groups of speakers who violated the maxims for different reasons. In the first group, there were two speakers who violated all maxims with the same reasons; in the second group, there were eighteen speakers that violated three different maxims based on different reasons as well; and in the last group, sixteen speakers violated two different kinds of maxims. The summary can be seen in Table 1.

Table 1. Relation of Violated Maxims and Their Reasons

\begin{tabular}{|c|c|c|c|}
\hline $\begin{array}{l}\text { Number of } \\
\text { violated } \\
\text { maxims }\end{array}$ & Violated maxims & $\begin{array}{l}\text { Number of } \\
\text { Characters }\end{array}$ & Reasons of lying \\
\hline 4 & QN, QL, RL, MN & 2 & $\begin{array}{l}\text { hide the truth, save face, satisfy } \\
\text { the hearer, cheer the hearer, } \\
\text { build someone's belief, } \\
\text { convince the hearer }\end{array}$ \\
\hline \multirow[t]{3}{*}{3} & a. QN, QL, RL & 10 & $\begin{array}{l}\text { hide the truth, feel jealous, } \\
\text { cheer the hearer, build } \\
\text { someone's belief, convince the } \\
\text { hearer }\end{array}$ \\
\hline & b. QN, QL, MN & 7 & $\begin{array}{l}\text { hide the truth, save face, cheer } \\
\text { the hearer, build someone } \\
\text { belief, Convince the hearer }\end{array}$ \\
\hline & c. QL, RL, MN & 1 & hide the truth, save face \\
\hline 2 & a. QL, RL & 10 & $\begin{array}{l}\text { hide the truth, save face, build } \\
\text { someone's belief, } \\
\text { convince the hearer }\end{array}$ \\
\hline & b. QN, QL & 6 & $\begin{array}{l}\text { hide the truth, save face, cheer } \\
\text { the hearer, build someone's } \\
\text { belief, convince the hearer }\end{array}$ \\
\hline
\end{tabular}

Note:

QN $=$ Quality

$\mathrm{QL}=$ Quality

$\mathrm{RL}=$ Relevance

$\mathrm{MN}=$ Manner 


\section{Violating all maxims}

The purpose of the characters to violate all maxims was to eliminate any chance for the interlocutor to respond. Based on the data, the characters lied for different reasons such as hiding the truth, saving the speaker's or the hearer's face, satisfying the hearer by giving an appropriate utterance or responses that might cheer the hearer or avoid to hurt the hearer. Besides, the characters also wanted to build someone's belief so that they could convince the interlocutor with no doubt. This can be seen in the following example:

(Setting: Lynette's House - In the kitchen, Tom is reading the paper at the table while Lynette sorts through work papers. Parker runs downstairs.)

Tom : Ok, listen. Do not worry about it. I am sure Mrs. Mulberry is around here

Lynette: Or .. maybe she is not. She could have left; you know maybe she had some other little boys that she needed to help.

Parker : Like who?

Lynette : I do not know. It could be a little boy in uh .. England, named ... Spencer.

Tom : Lynette

Lynette: This is conjecture on my part, but it is possible that someone like little Spencer needs Mrs. Mulberry more because he does not have a daddy and a mommy who loved him. Yeah, that is it. He is an orphan with no hands, ok? You are so sweet. Come here. I love you, are you alright? Ok, go get dressed.

$\rightarrow$ Lynette lied to her son, Parker, by saying that Mrs. Mulberry left Parker on her own initiative.

\section{Fact:}

- Lynette was lying in bed, awake. She got up and went into Parker's room. He was sleeping and his umbrella had fallen to the floor. Lynette stroked Parker's head, and grabbed the umbrella.

- Lynette went to the trash can. She opened it and jammed the umbrella inside 


\begin{tabular}{|c|c|c|c|c|c|}
\hline \multirow{2}{*}{ Speaker } & \multirow{2}{*}{ Utterances } & \multicolumn{4}{|c|}{ Violation of Maxims } \\
\hline & & QN & $\mathbf{Q L}$ & $\mathbf{R L}$ & $\mathbf{M N}$ \\
\hline Lynette & $\begin{array}{l}\text { This is conjecture on my part, but } \\
\text { it is possible that someone like } \\
\text { little Spencer needs Mrs. } \\
\text { Mulberry more because he does } \\
\text { not have a daddy and a mommy } \\
\text { who loved him. Yeah, that is it. } \\
\text { He is an orphan with no hands, } \\
\text { ok? You are so sweet. Come here. } \\
\text { I love you, are you alright? Ok, go } \\
\text { get dressed. }\end{array}$ & $\sqrt{ }$ & $\sqrt{ }$ & $\sqrt{ }$ & $\sqrt{ }$ \\
\hline
\end{tabular}

Lynette did multiple violations. She violated maxim of quantity because she gave too much explanations to Parker. She also exaggerated the utterances so that Parker would believe her. For example, Lynette exaggerated the story (violated maxim of manner) that Spencer was an orphan with no hands. Besides, Lynette also violated maxim of relevance by being not relevant to Parker's questions, then avoiding talking about something by changing the conversation topic abruptly. For example, at the end of the conversation, she immediately changed the topic "Come here. I love you, are you alright? Ok, go get dressed" so that Parker would ask no more questions and her lies could be covered perfectly

Lynette violated all maxims because she wanted to hide the truth that actually she fired Mrs. Mulberry. She also wanted to save her face for still being the best mom, and at the same time wanted to cheer Parker by saying "You are so sweet". She believed that her son, Parker, was just a little boy so he did not need the true information. She wanted to convince Parker by comparing him with little Spencer, an orphan with no hands, so that he needed Mrs. Mulberry more than Parker who still had mom who loved him ("I love you, are you alright?"). She convinced her son that she told the truth and this was proved when Parker asked no more questions.

Finally, Lynette actually wanted to concern about someone's positive and negative face. She focused on positive face because she wanted to cheer Parker and was sure that Parker did not need the true information; therefore, she focused on Parker's positive face to express her intention. Besides, Lynette also tried to focus on someone's negative face since she 
did not want her action to be unimpeded especially by Parker, so that Lynette could reach her goal easily.

\section{Violating three maxims}

The purpose of the characters that violated the three maxims seemed to fulfill the reasons of lying, that is, to hide the truth that the speakers felt jealous about something, to cheer or not to hurt the interlocutor so that the speaker could build the interlocutors' belief and convince them. It seemed that the speakers tried to cover the truth by cheering and convincing the interlocutor so that the speakers could achieve their desire easily. There were three groups of violated maxim, that is, maxim of quantity, quality, and relevance; maxim of quantity, quality and manner, and the last was maxim of quality, relevance and manner.

\section{a. Violating maxims of quantity, quality, relevance}

(Setting: Outside Susan's House. Susan is washing the trailer when Tom approaches.)

Tom : Susan, have you talked to Lynette?

Susan : Um, no. Have you tried her cell?"

Tom : Yeah, she isn't picking up. Do you know where she is?

Susan : Uh, no, I'm sorry.

Tom : Susan, I think you do.

Susan : I really don't, Tom. Is everything okay?

$\rightarrow$ Susan lied to Tom that she did not know where Lynette was.

Fact: Susan dialed Lynette's cell phone and told her that Tom tried to look for his wife and sons.

\begin{tabular}{|c|c|c|c|c|c|}
\hline \multirow{2}{*}{ Speaker } & \multirow{2}{*}{ Utterances } & \multicolumn{4}{|c|}{ Violation of Maxims } \\
\hline & & QN & QL & RL & $\mathbf{M N}$ \\
\hline Susan & Um, no. Have you tried her cell & $\sqrt{ }$ & $\sqrt{ }$ & $\sqrt{ }$ & \\
\hline
\end{tabular}

In this case, Susan lied to Tom that she did not know where Lynette was. However, the truth was Susan knew where exactly Lynette and her children were. Susan did it because she had promised Lynette to keep silent when Tom asked about it. Susan wanted to protect Lynette and did not want to impede Lynette's family problem. 
When Tom asked Susan where Lynette was, Susan was uninformative by giving too short answer. Besides, she also tried to change the topic of the conversation by asking Tom back whether he had tried Lynette's cell phone or not when she said "Have you tried her cell?", so that Tom would believe that Susan had nothing to do with it. Thus, Susan violated maxim of quantity by giving too short, uninformative and unclear information. She also violated maxim of relevance by changing the topic of the conversation and avoided talking about it when she asked "Is everything okay?"

She violated three of the four maxims because she wanted to concern about someone's positive face, that is, to hide the truth that she actually knew where Lynette and her sons were without hurting Tom's feeling. Susan wanted to cheer Tom by giving no accusation to him and at the same time also to cheer Lynette by keeping her secret.

\section{b. Violating maxims of quantity, quality and manner}

(Setting: At Nora's house. Nora has a little chitchat with Tom when he sends Kayla home)

Nora : You know Tom, I have tasted your pizza and I have to be perfectly honest with you. It was like I died and went to Italy.

Tom : Really?

Nora : Oh my God. You are born to do this and I just hate to see you give it up, because well... man, this is none of my business but Lynette does bully you sometimes.

$\rightarrow$ Nora lied to Tom that she had tasted Tom's pizza before and that she agreed with Tom's idea and hated it when Tom decided to give it up.

Fact: The conversation was between Nora and Tom about her disagreement with Tom's idea.

\begin{tabular}{|c|c|c|c|c|c|}
\hline \multirow{2}{*}{ Speaker } & \multirow{2}{*}{ Utterances } & \multicolumn{4}{|c|}{ Violation of Maxims } \\
\hline & & QN & $\mathbf{Q L}$ & RL & $\mathbf{M N}$ \\
\hline Nora & $\begin{array}{l}\text { You know Tom, I have tasted } \\
\text { your pizza and I have to be } \\
\text { perfectly honest with you. It was } \\
\text { like I died and went to Italy }\end{array}$ & $\sqrt{ }$ & $\sqrt{ }$ & & $\sqrt{ }$ \\
\hline
\end{tabular}

Nora lied to Tom by saying that she had tasted Tom's pizza and it was amazing. In her utterances, she violated maxim of quality and quantity by 
giving too short or too little information and also exaggerated the utterances that made her also violate maxim of manner.

By violating three maxims, Nora actually wanted to concern about the person's negative face, that she did not want her action to be impeded by others. In this case, Nora was jealous with Lynette. It could be obviously seen when she said "Lynette does bully you sometimes"; she wanted to steal Tom from her and build his belief that she was the one who cared about Tom so much, more than his wife did. Nora convinced Tom not to give up when she said "You are born to do this and I just hate to see you give it up" so that Tom would probably fall in love with her.

\section{c. Violating maxims of quality, relevance, and manner}

(Setting: Wisteria Lane-Daytime. A police car pulls up. A crowd of neighbors gather to see what's happening. Susan and the officer walk to Mike's house. The crowd follows. Mike opens the front door. She points across the street where Paul is raking his leaves)

Police Officer : "Your girlfriend said Mr. Young confessed a murder to you?"

Mike : : "Um, no. No, not to me."

Police Officer : "And I don't suppose you have a journal that belonged to a Martha Huber?"

Mike : "No. I hardly knew her. Besides, you ever had known a woman who'd loan out her diary?"

Susan : : "Mike, what are you doing?"

Mike : "I'm sorry, Susan. I don't know what you're talking about. But I've go a job to get to. Is there anything else?"

$\rightarrow$ Mike told a lie to the police officer by saying that he did not know anything about Martha Huber and her diary.

Fact: Mike confessed to Susan that he lied to the police officer in order to protect Susan and himself.

\begin{tabular}{cccccc}
\hline \multirow{2}{*}{ Speaker } & \multirow{2}{*}{ Utterances } & \multicolumn{4}{c}{ Violation of Maxims } \\
\cline { 3 - 6 } & & QN & QL & RL & MN \\
\hline Mike & Um, no. No, not to me & & $\sqrt{ }$ & $\sqrt{ }$ & $\sqrt{ }$ \\
\hline
\end{tabular}

Mike violated three maxims, that is, maxims of quality, relevance and manner. His utterance "no, not to me" was ambiguous because he made 
people think that Paul Young did confess to someone else but not to him. It meant that Paul Young had possibility to do the murder. Mike also violated maxim of relevance because he actually hid the fact that Paul Young did confess to him about the murder.

In this case, Mike violated the maxims in order to tell a lie to the police officer by telling that Paul Young never confessed a murder to him. He did it because he wanted to hide the truth that might put him in trouble. He also wanted to save his face in front of his entire neighbors so that they would not make gossip about him.

Mike violated the three maxims because he wanted to focus on someone's negative face, that is, to have freedom of any of his actions, so that he could cover his lies easily. By focusing on someone's negative face, he also wanted to convince the police officer that he did not have any connection with Paul's case, so that the police officer would leave him alone.

\section{Violating two maxims}

The characters that violated only two of the four maxims wanted to hide the truth, save face, cheer the hearer, and as a result, they could build the interlocutors' belief and convince them. However, they gave the impression that they wanted to lie gradually with the focus on building someone's belief in order to create another lie in the future. There were two groups of violated maxim: maxims of quantity and quality, and maxims of quality and relevance.

\section{a. Violating maxims of quantity and quality}

(Setting: Lynette's House - Tom is packing in the bedroom)

Lynette: "Atlantic City?"

Tom : "Yeah, it's last minute, but Jerry got a great deal on a suite at one of the casinos and a bunch of the old gang is coming in from New York and, God, it's been forever since I have been so, how could I turn that down?"

Tom : "I have been going to Atlantic City for business. I am up for a top spot with Jerry's firm, Huffington Promotions. And if you don't believe me, you can call the CEO himself."

$\rightarrow$ Tom lied to Lynette that his trip had a business purpose. 
Fact: Lynette had followed Tom to a house in the suburbs. She saw a pretty young woman handed Tom a glass of wine. The woman walked right up to the front door and watched through the window as Tom followed the young woman upstairs. Tom admitted and told Lynette his real purpose to go to Atlantic City.

\begin{tabular}{|c|c|c|c|c|c|}
\hline \multirow{2}{*}{ Speaker } & \multirow{2}{*}{ Utterances } & \multicolumn{4}{|c|}{ Violation of Maxims } \\
\hline & & QN & QL & RL & $\mathbf{M N}$ \\
\hline Tom & $\begin{array}{l}\text { Yeah, it's last minute, but Jerry got a } \\
\text { great deal on a suite at one of the } \\
\text { casinos and a bunch of the old gang } \\
\text { is coming in from New York and, } \\
\text { God, it's been forever since I have } \\
\text { been so, how could I turn that } \\
\text { down?" }\end{array}$ & $\sqrt{ }$ & $\sqrt{ }$ & & \\
\hline
\end{tabular}

Tom absolutely told a lie, because he did not do any business in Atlantic City. His lies were done on purpose. First, he wanted to build someone's belief in order to create and smooth other lies in the future. Second, he did not want to hurt Lynette's feeling.

Tom violated two maxims, that is, maxims of quantity and quality. He violated maxim of quantity by making contribution more informative than was required in order to convince Lynette. This could be seen when Tom explained his trip's purpose without being asked first by Lynette. He said "Yeah, it's last minute how could I turn that down?"

Tom's purpose of violating the maxims was because he wanted to cover his real activity in Atlantic City. Besides, he wanted to avoid Lynette from asking lots of questions that he probably could not answer. Therefore, he gave Lynette full, detailed information (violated maxim of quantity). By violating the two maxims, Tom actually wanted to be concerned about the person's positive face, and to emphasize that both speakers actually wanted the same thing and had the common goal, that is, to loose Lynette's hunch that Tom had an affair.

\section{b. Violating maxims of quality and relevance}

(Setting: Nora was sitting in her living room when Lynette came and asked her for an explanation) 
Nora : I do not know what Tom told you about, but he came on to me.

Lynette : I am sorry; I did not quite catch that. Do not you just come on over here and say that to me again?

$\rightarrow$ Nora told a lie by saying that Tom actually was the one who came to her.

Fact: Nora came to Tom's place (at his new restaurant), bought a dinner and tried to flirt him when he was alone

\begin{tabular}{clcccc}
\hline \multirow{2}{*}{ Speaker } & \multicolumn{2}{c}{ Utterance } & \multicolumn{4}{c}{ Violation of Maxims } \\
& & QN & QL & RL & MN \\
\hline Nora & $\begin{array}{l}\text { I do not know what Tom told } \\
\text { you about, but he came on to } \\
\text { me }\end{array}$ & & $\sqrt{ }$ & $\sqrt{ }$ & \\
& & & & \\
\hline
\end{tabular}

In this case, Nora told a lie by saying that Tom was the one who came to her and tried to flirt her. She did it because she wanted to hide the truth that she was actually the one who came to Tom and tried to flirt him. Besides, she wanted to save her face since she realized that Lynette's coming was to ask for her explanation in visiting Tom.

In order to smooth her lies, she violated maxim of quality and maxim of relevance. When Nora said "I do not know what Tom told you about, but he came on to me", she violated maxim of relevance by doing the wrong casualty. Why was it so? Nora gave an answer before Lynette asked her a question. However, Nora's first utterance was considered to violate maxim of manner by being ambiguous. The reason was that Nora did not give any further explanation about what she was talking about. The reason why Nora violated two of the four maxims was because she wanted to be concerned about the person's negative face, that is, about the will of every member that his/her action was unimpeded by others. In this case, Nora wanted Lynette to leave her alone and forget about what she had done to Tom before.

\section{CONCLUSION}

From the analysis above, it could be concluded that even though Grice (1975) proposes the Cooperative Principle in communication, in some situations, people disobeyed them deliberately. When people violated the 
maxims, they seemed to have their own reasons for doing it. The writer found out that the characters in Desperate Housewives film used the violation of maxims as the strategy to tell lies. The lying reasons varied from one to another in accordance with the purposes they wanted to reach. The violation of maxims happened because the characters wanted to eliminate any chance for the interlocutor to respond so that the interlocutor would ask no more question and the characters could achieve their goals easily. Some characters who wanted to cover the truth by focusing on cheering and convincing the hearer, violated a certain number of maxims, that is, a combination of maxims of quantity, quality, relevance or maxims of quantity, quality, manner or maxims of quality, relevance and manner. Meanwhile, if the characters had a tendency to lie gradually by building someone's belief, they violated two maxims, that is, a combination of either maxims of quality and quantity or maxims of quality and relevance

Hopefully, this finding would improve the understanding of the violation of maxims specifically for lying purposes and enable people to see what is behind one's utterances.

\section{REFERENCES}

Brown, G., \& Yule, G. (1983). Discourse analysis. Cambridge: Cambridge University Press.

Christoffersen, D. (2005). The shameless liar's guide. Sourcebooks.

Crowley, D., \& Mitchell, D. (1994). Communication theory today. Oxford: Blackwell Publishers.

Cutting, J. (2002). Pragmatics and discourse: A resource book for students. Routledge: London and New York.

Desperate Housewives. (n.d.). Retrieved February 27, 2007, from http://desperatehousewives.ahaava.com

Grice, H. P. (1975). Logic and conversation. In P. Cole, \& J. Morgan (Eds.), Syntax and semantics 3: Speech Acts (pp. 4-5). New York: Academic press

Wikipedia Ensiklopedia Bebas. (2007). Desperate Housewives. Retrieved February 27, 2007, from http://en.wikipedia.org/wiki/Desperate_Housewives 